\title{
Numerical modelling of retrofitting an industrial boiler type OP-230 for predicting NOx reduction
}

\author{
Przemysław Motyl ${ }^{1, *}$, Jan Lach $^{2}$ \\ ${ }^{1}$ Kazimierz Pulaski University of Technology and Humanities in Radom, Faculty of Mechanical Engineering, \\ Malczewskiego 29, 26-600 Radom, Poland \\ ${ }^{2}$ Bialystok University of Technology, Faculty of Engineering Management, Ojca Tarasiuka 2, 16-001 Kleosin, Poland
}

\begin{abstract}
This study focuses on the indirect co-firing CFD simulations of reductions in NOx emissions relative to the coal combustion. For the given biomass-derived syngas composition and $15 \%$ syngas heat input, two arrangements of nozzles dedicated to the syngas injection into the furnace of an older PC-fired boiler of type OP-230 with low-emission burners on the front wall were chosen to investigate the impact of their location on the reduction in NOx emissions. It was shown that the highest reduction achieved by means of the improvement of the air staging via the dual-fuel technique can reach up to $40 \%$ (Case 1 : nozzles at the elevation of the bottom row of burners) and up to $32 \%$ (Case 2: nozzles above the upper level of the burners). The modelling results also showed that one can meet the requirements for co-firing of coal with waste derived syngas. The boiler can be retrofitted for the fulfilment of the prospective environmental protection regulations relating to levels of NOx emissions by combining the described technology with SNCR methods. It is also very important that the indirect co-firing enables reduction of carbon dioxide emissions proportionally to the syngas heat input.
\end{abstract}

\section{Introduction}

The direct and indirect biomass co-firing with coal are widely regarded as environmentally friendly technologies that can provide the commonly known benefits although they also have their disadvantages [1$3]$. This study is conducted to determine whether a PCfired boiler of type OP-230 with low-emission burners on the front wall can be effectively retrofitted via indirect biomass co-firing for the fulfilment of the prospective environmental protection regulations relating to levels of NOx emissions. The problem is of modifying the standard air staging technique, originally adapted for lowering NOx emissions slightly below $400 \mathrm{mg} / \mathrm{Nm} 3$, by biomass-derived syngas injection above or below the existing coal burners into the furnace through dedicated nozzles offering the largest flexibility in volumetric flow rate. This solution leads to the improvement of the air staging via the dual-fuel technique and its integration with low-NOx coal burners relative to the combustion of coal. The expected reduction in NOx emissions depends on arrangement of syngas nozzles, syngas composition and heat input replacement. The last factor determines the amount of avoided $\mathrm{CO} 2$ emissions. The various attractive ways to modify low-NOx emission burners and the air distribution with the use of OFA, ROPA and SOFA nozzles may be found in [4-5]. The overview of NOx reduction technology is also done e.g. in [6-7]. Experiences with the commercial implementation of indirect co-firing technology were acquired mainly in
Finland (the Kymijärvi PC-fired CHP plant, Kymijärvi II power plant and the Vaskiluodon Voima plant in Vaasa) but also in Austria (the Zeltweg PC-fired power plant), Belgium (the installation at Ruien) and the Netherlands (the installation at Geertruidenberg) [3,8-9]. A large part of currently conducted research is focused on co-firing simulations with help of ANSYS Fluent CFD software [10] and other CFD software packages [11]. For example, the detailed numerical results for several options of co-firing the paper rejects syngas in a coalfired boiler were reported in [11]. They are focused on the NOx and CO emissions and furnace LOI depending on syngas heat input and furnace stoichiometry. The highest NOx reduction of $46 \%$ relative to the coal combustion corresponded to $23 \%$ heat replacement. The simulations of the indirect biomass co-firing in a $600 \mathrm{MW}$ tangential PC-fired boiler with $14 \%$ heat input injection through the lowest layer burner conducted in [12] showed first of all that NOx emission can be reduced about $50-70 \%$ relative to the baseline case (no syngas). The results of similar simulations of co-firing the sewage sludge syngas in a PC-fired OP-650 boiler are given in [13]. The technical feasibility of co-firing biodegradable waste-derived LCV syngas as much as 10 , 20 and $40 \%$ by heat input with coal in a $230 \mathrm{t} / \mathrm{h}$ dual PCgas fired boiler was investigated in [14]. Examining two extreme calorific values, it was discovered that the higher the syngas heat content, the greater coal substitution without the serious impact on boiler operation. The results of above studies give only some

\footnotetext{
* Corresponding author: p.motyl@gmail.com
} 
idea of the magnitude of NOx reduction relative to the baseline achieved under indirect co-firing different syngas with coal in selected PC-fired boilers. Therefore, for a given boiler and a type of coal and syngas, the reduction in NOx emissions cannot be predicted a priori from known hitherto data. It can be determined through proper research. This justifies the use of our own numerical simulations to conduct the evaluation of reductions in NOx concentrations in the furnace of a PCfired boiler of type OP-230 with low-emission burners on the front wall. The comparison of the results obtained with the prospective standards of NOx emissions will answer the question formulated above. Simultaneously, it will turn out whether the syngas derived from agro biomass and fuels from waste containing such troublesome components as chlorine and alkali can be co-fired with coal.

\section{Formulation of the problem}

The basic data of the boiler are as follows: size $8 \mathrm{~m} \times 26.7 \mathrm{~m} \times 8.66 \mathrm{~m}$, coal consumption $\mathrm{Bc}=8.242 \mathrm{~kg} / \mathrm{s}$, primary and secondary air volume flow rate (and temperature) -14.48 and $25.96 \mathrm{Nm} 3 / \mathrm{s}(378$ and $603 \mathrm{~K}$ ), respectively. The secondary air swirl is in line with the burner manufacturer recommendations. The boiler is equipped with (i) eight low-emission burners located at three levels on the front wall and characterized by the concentric dust nozzle supplying a fuel-dust-air mixture into the dust separator in which the mixture is divided into independent streams with alternately high and low concentration of dust coal favouring the formation of a reduction zone; (ii) twelve OFA nozzles installed on both opposite walls; and (iii) two bottom air nozzles located on the side walls in the region near the bottom of the main burners. The air staging system with OFA nozzles ensures complete combustion. The amount of air supplied to the boiler is controlled by monitoring flue gas oxygen level at the outlet from the furnace.

Table 1. Basic properties of coal

\begin{tabular}{|c|c|}
\hline Item & Value \\
\hline \multicolumn{2}{|c|}{ Proximate analysis [wt\%] } \\
\hline Moisture & 12.4 \\
\hline Volatile matter & 22.5 \\
\hline Fixed carbon & 52.5 \\
\hline Ash & 12.6 \\
\hline \multicolumn{2}{|c|}{ Ultimate analysis [wt\%] DAF } \\
\hline Carbon & 80.77 \\
\hline Hydrogen & 5.87 \\
\hline Oxygen & 10.93 \\
\hline Nitrogen & 1.73 \\
\hline Sulfur & 0.29 \\
\hline Chlorine & 0.40 \\
\hline & 23.44 \\
\hline LHV [MJ/kg]
\end{tabular}

Table 2. Composition of co-fuel [15] (standard temperature $20^{\circ} \mathrm{C}$ and pressure $1013 \mathrm{hPa}$ )

\begin{tabular}{|c|c|}
\hline \multicolumn{2}{|c|}{ Components [\%mol] } \\
\hline Item & Value \\
\hline $\mathrm{CO} 2$ & 22.93 \\
\hline $\mathrm{CH} 4$ & 9.27 \\
\hline $\mathrm{CO}$ & 30.91 \\
\hline $\mathrm{H} 2$ & 36.89 \\
\hline \multicolumn{2}{|c|}{} \\
\hline $\mathrm{LHV}[\mathrm{MJ} / \mathrm{kg}]$ & 11.97 \\
\hline
\end{tabular}

For the $100 \%$ boiler load, six of eight available burners were active in our simulations. The necessary settings were fixed according to the Fluent packet documentation. The mesh system consists of 990000 polyhedral cells. The hybrid Finite-Rate/EddyDissipation model [10] was used to describe the combustion of coal and the co-firing process. The kinetic data are taken from [15-16]. The standard k- $\varepsilon$ turbulence model enables the turbulent Reynolds equations to be closed. The Discrete Ordinates radiation model was used to simulate the radiation heat transfer. The combustion of coal is the baseline case (Case 0). The coal chemical composition is given in Table 1 . We limit ourselves to study of co-firing one syngas whose chemical composition is presented in Table 2. In order to evaluate its impact on the reduction in NOx emissions, two arrangements of nozzles were simulated: (i) four nozzles at the elevation of the bottom row of burners (Case 1); and (ii) two nozzles on the front wall above the upper level of the burners (Case 2). These two simulations were conducted under the assumption that the heat replacement is equal to $15 \%$. The co-fuel was fed to the furnace through nozzles of a diameter providing a gas velocity within 25 to $30 \mathrm{~m} / \mathrm{s}$ to ensure gas supply to the center of the combustion chamber. The indicated two arrangements of nozzles resulted in different oxygen concentration and temperature profile in the furnace. The results achieved are compared with those for the baseline (Case 0 ). The gas supply was accompanied by a change of air distribution in the furnace. The reduced amount of combusted coal dust allowed to move the air from the burners to the OFA nozzles. To simplify a comparative analysis it was assumed that the syngas temperature at the inlet to the boiler was the same in Case 1 and Case 2 and equal to $1000 \mathrm{~K}$.

\section{Results and discussion}

The first stage of numerical simulations consisted of reproducing the coal combustion conditions (Case 0) using the inputs taken from the recommendations of the boiler and coal burner manufacturers. The average values: $\mathrm{T}=1340 \mathrm{~K}, \quad \lambda=1.23, \quad \mathrm{O} 2=3,6 \% \quad$ dry, $\quad$ and $\mathrm{NOx}=380 \mathrm{mg} / \mathrm{Nm} 3(6 \% \mathrm{O} 2$, dry) at the furnace exit (Figs. 1 and 2) are within the range declared in the boiler manual and are taken as the reference points for the indirect co-firing analysis (Case 1 and Case 2). 


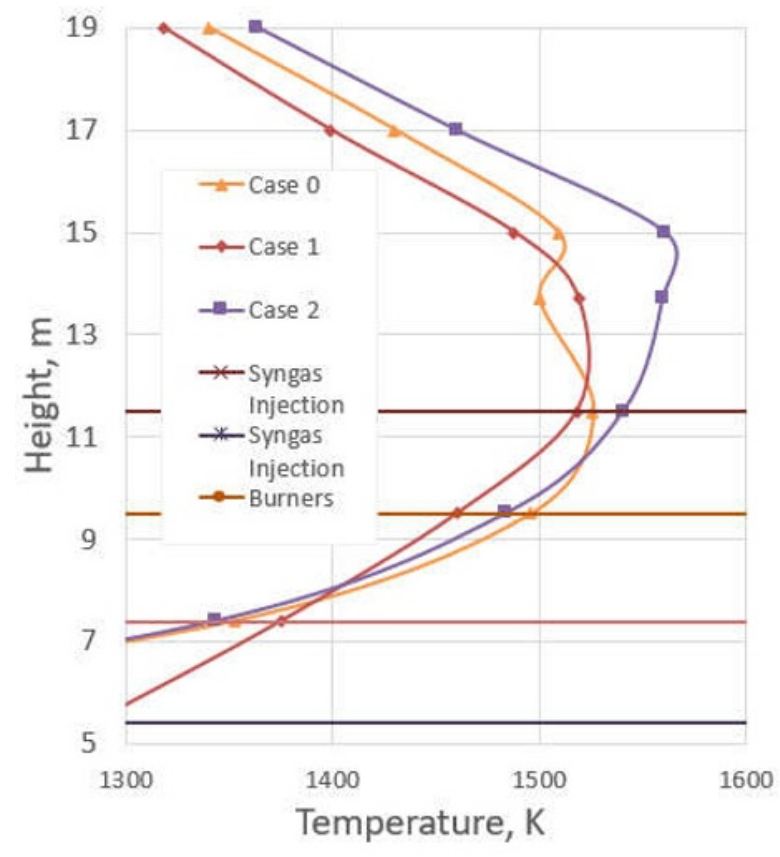

Fig. 1. Mean temperature distribution along the furnace elevations.

Fig. 1 shows two peaks of temperature which are slightly displaced towards the rear wall because the burners are located on the front wall. The first peak above the burners is due to the course of the combustion process at region of burners. Next, the following drop in temperature reaches the OFA nozzles. The coal burnout results in slight increase in temperature above OFA nozzles corresponding to the second peak. The results of the second stage of simulations are related to Case 1 and Case 2. On one hand, the syngas low heat content relative to coal and increased moisture content resulting from methane and hydrogen combustion (Table 2) cause a lowering of flame temperature (i.e. flame cooling effect) in the burner zone as shown in Figs. 1 to 3. On the other hand, the syngas co-firing increases the temperature near the co-fuel nozzles.

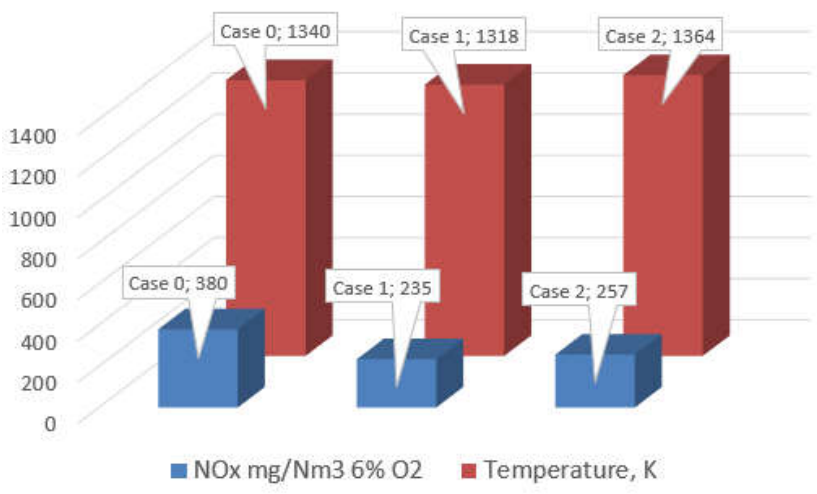

Fig. 2. Mean temperature and NOx concentration at the furnace exit.
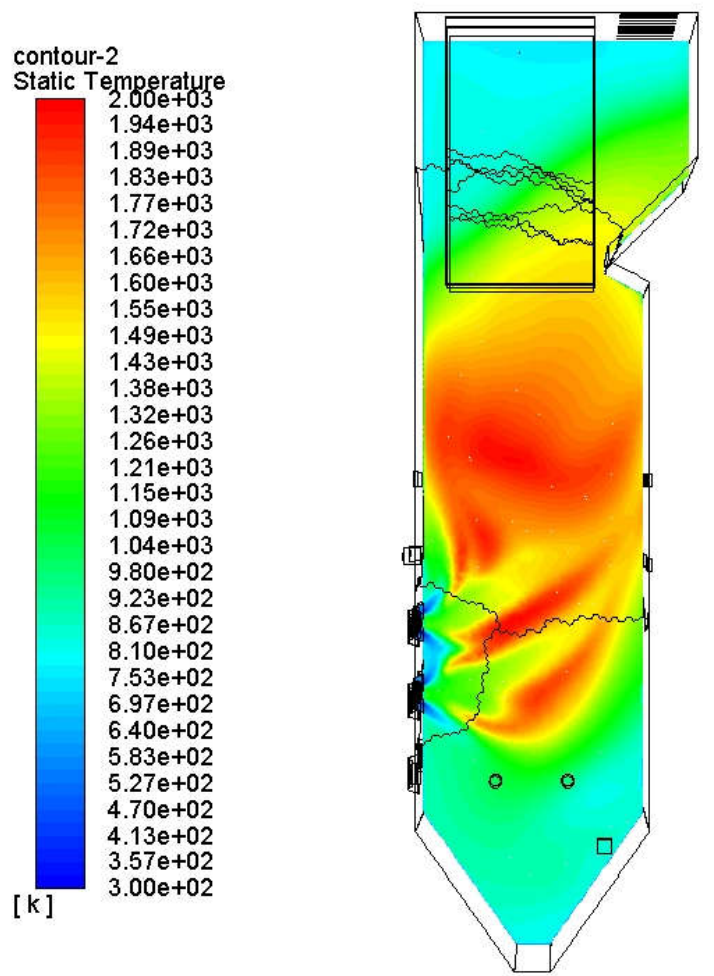

Fig. 3. Temperature profile in the furnace (Case 2)
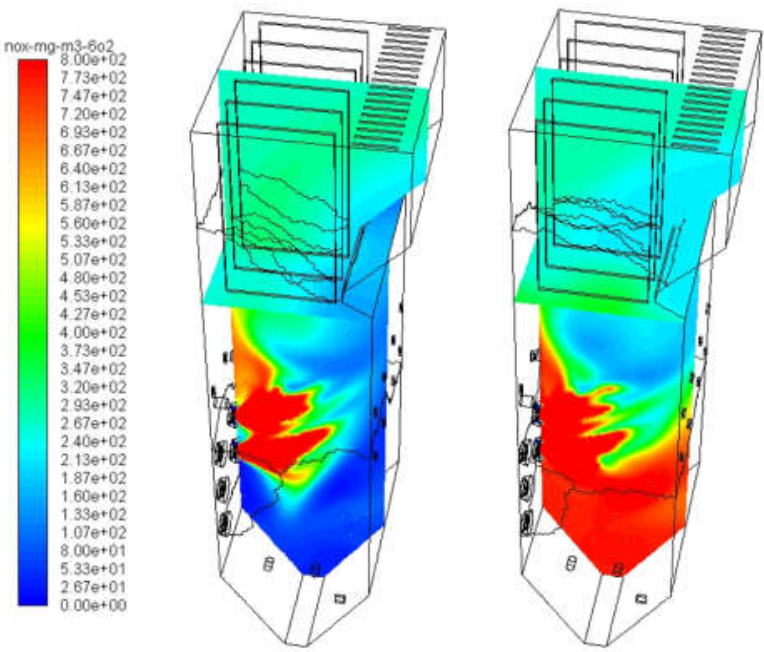

Fig. 4. NOx values $[\mathrm{mg} / \mathrm{Nm} 3]$ for the Case 1 and Case 2.

Comparing the mean temperatures at the furnace exit (Fig. 2), we can conclude that the amount of co-fuel injection in Case 2 is limited because such an injection at the elevation of the upper row of burners while increasing the amount of air in OFA nozzles raises the local temperature in the burnout zone as illustrated in Fig.3. Further increase of gas flow rate can cause an adverse impact on the boiler operation. The NOx concentration along the entire height of the furnace is higher for Case 2 than for Case 1 (Fig. 4) which results from higher combustion temperature (Fig.1). This does not apply to the local fuel riche zone in which the NO is 
removed by hydrocarbons introduced into the furnace with the syngas injection in Case 2. The NOx concentration distribution obtained with Case 1 (Fig. 4) results from: (i) stable oxygen deficient conditions (Fig.5) in the zone of burners what is also illustrated in Fig.6; and (ii) limited successive uniform increase in oxygen concentration (Fig.5) up to levels of OFA nozzles and small amounts of NO production in the burnout zone; both due to the flame cooling effect. The syngas velocity ensuring its injection to the center of combustion chamber does not significantly affect the oxygen depletion near the screens. Decreasing the excess air in the main combustion zone has only a small impact on increasing the exposure of screens to low-oxygen and high-temperature corrosion in the region from burners to the level of OFA nozzles. Figs. 7 and 8 show that Case 1 and Case 2 ensure a long residence time of the co-fuels (more than two seconds) in the combustion chamber and not less than 2 seconds residence at the temperature above $1123 \mathrm{~K}$, respectively. The syngas can be therefore derived from gasification of agricultural residues biomass or containing such troublesome components as chlorine and alkali.
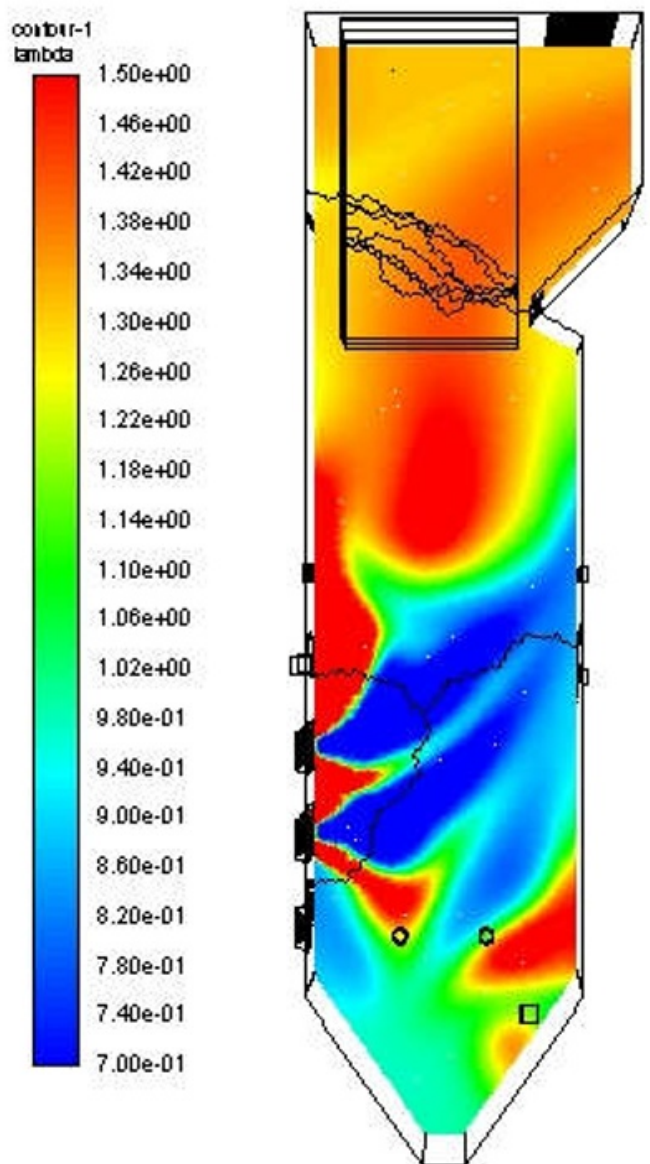

Fig. 5. Excess air ratio distribution in the furnace (Case 1).
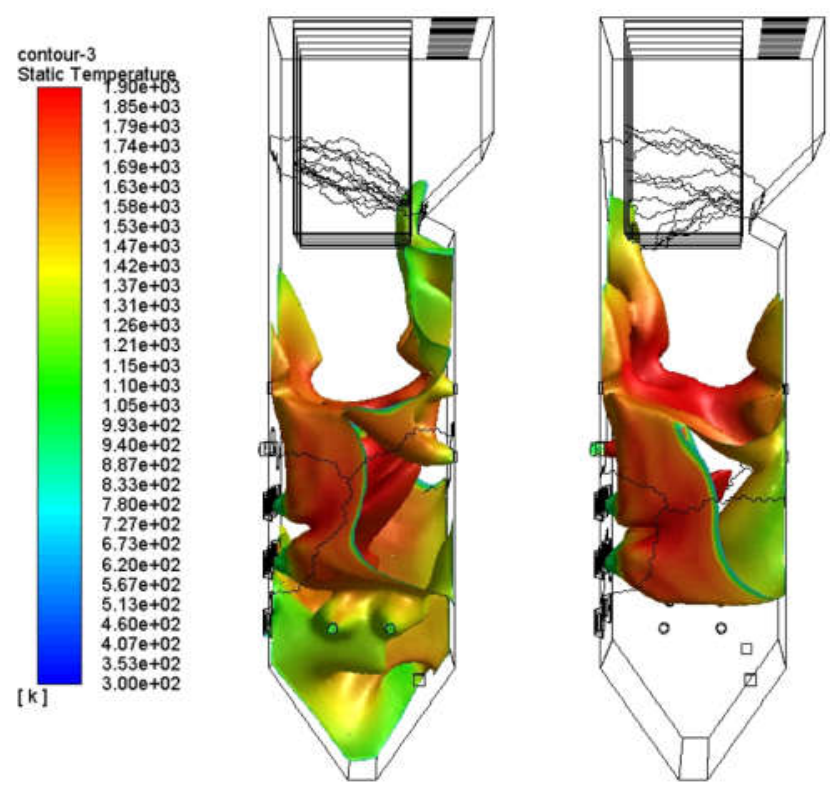

Fig. 6. Substoichiometric zone in the furnace (Case 1 - on the left, Case 2 - on the right) colored according to the temperature-color scale.
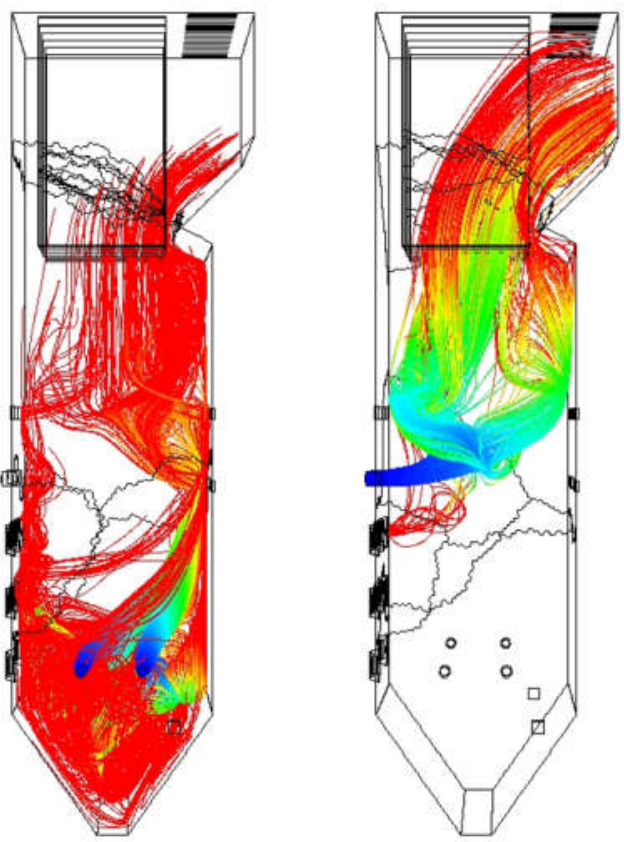

Fig. 7. Pathlines released from the dedicated syngas nozzles (Case 1 - on the left, Case 2 - on the right). 

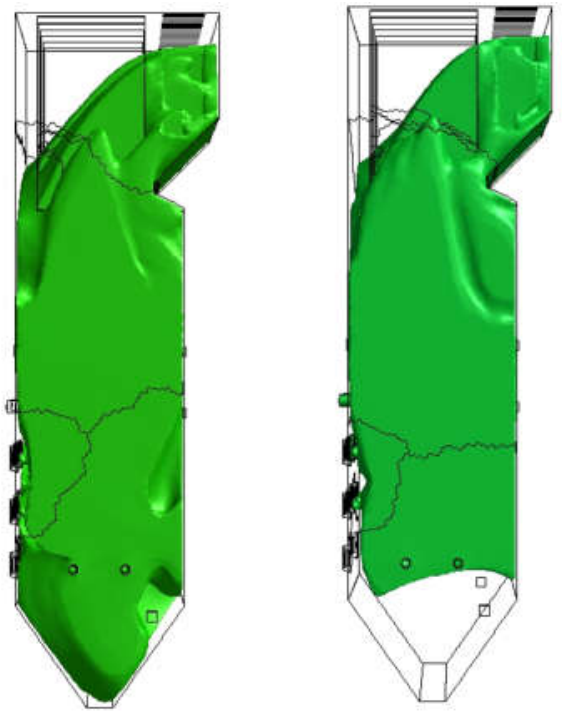

Fig. 8. Temperature region above $1123 \mathrm{~K}$ (Case 1 - on the left, Case 2 - on the right).

\section{Conclusions}

Our CFD simulations were directed at the evaluation of possibilities, limitations and benefits of the co-firing environmentally friendly biomass-derived syngas with coal in an older PC-fired boiler of type OP-230 with low-emission burners on the front wall still operating in Poland as heating units in combined heat and power (CHP) district energy plants. Particular attention was focused on the evaluation of reductions in NOx emissions relative to the coal combustion. For the biomass-derived syngas composition (Table 2) and 15\% heat input replacement, two arrangements of nozzles dedicated to the syngas injection into the furnace were chosen to investigate the impact of their location on the reduction in NOx emissions. Ensuring the optimal operating conditions of the boiler, it was shown that the highest reduction achieved by means of such an improvement of the air staging via the dual-fuel technique can reach up to $38 \%$ (Case 1) and up to $32 \%$ (Case 2). The modelling results also showed that one can meet the requirements for co-firing of coal with syngas produced by gasification of agricultural and agro industrial residues $[17,18]$ as well as solid recovered fuels (SRFs) containing such troublesome components as, for example, chlorine and alkali Note that there is particular interest in gasification of agro biomass renewing every year. Fortunately, the mentioned troublesome component remain in the gasifier as slag and ash that are removed from there, therefore does not enter the boiler. Thus, it is easier to use ashes obtained from co-firing as additive for concrete production. The gasification of agro biomass and fuels formed from waste (SRFs, RDFs, REFs) is probably the forward looking technology that can even play a key role in the use of these combustible substances in the future energy sector. In the latter case, we would have to deal with a way to reduce the amount of waste deposited in landfills. The prospective environmental protection regulations relating to NOx emissions can be fulfilled by combining the described technology with SNCR methods. It is also very important that the indirect co-firing enables reduction of carbon dioxide emissions proportionally to the syngas heat input.

\section{Acknowledgements}

Research have been carried out in the framework of 3190/23/P and S/WZ/1/2015 works financed by Ministry of Science and Higher Education from the funds for science.

\section{References}

1. J.U. Watts, A.N. Mann, D.L. Russel, An overview of NOx control technologies demonstrated under the Department of Energy's Clean Coal Technology Program (U.S. DOE, Federal Energy Technology Center, 2000)

2. C.D. Holland, A Summary of NOx Reduction Technologies (Texas Institute for Advancement of Chemical Technology, 2002)

3 R. Fernando, Experience of indirect cofiring of biomass and coal (IEA Clean Coal Centre, London, UK, 2002)

4. C. Zhou, Y. Wang, Q. Jin, Q. Chen, Y. Zhou, J. ENERGY INST. (to be published)

5. S. Chen, B. He, D. He, Y. Cao, G. Ding, X. Liu, Z. Duan, X. Zhang, J. Song, X. Li, Energy 122, 287-300 (2017)

6. R.D. Bell, F.P. Buckingham, An overview of technologies for reduction of oxides of nitrogen from combustion furnace

(https://www.mpr.com/uploads/news/nox-reductioncoal-fired.pdf)

7. R.K. Srivastava, R.E. Hall, S. Khan, K. Culligan, B.W. Lani, J. Air \& Waste Manage. Assoc. 55, 9, 1367-1388 (2005)

8. R. Fernando, Co-gasification and indirect cofiring of coal and biomass (IEA Clean Coal Centre, London, UK, 2009)

9. M. Blomberg, Fuel conversion at the Vaasa power plant: Large-scale biomass gasification plant integrated to a coal-fired boiler (http://biofuelregion.se/wpcontent/uploads/MauriBlomberg-Vaskilouden-Voima-Oy.pdf)

10. ANSYS ${ }^{\circ}$ Academic Research Fluent Manual, Release 18

11. K.T. Wu, H.T. Lee, C.I. Juch, H.P. Wan, H.S. Shim, B.R. Adams, S.L. Chen, Fuel 83, 1991-2000 (2004)

12. C. Dong, Y. Yang, R. Yang, J. Zhang, Appl. Energy 87, 2834-2838 (2010)

13. W.P. Adamczyk, S. Werle, A. Ryfa, Appl. Therm. Eng. 73, 343-350 (2014)

14. S. Kalisz, M. Pronobis, D. Baxter, Energy 33, 17701778 (2008)

15. R. Chacartegui, M. Torres, D. Sánchez, F. Jiménez, A. Muñoz, T. Sánchez, Fuel Process. Technol. 92, 213-320 (2011)

16. L. Chen, S.Z. Yong, A. Ghoniem, Prog. Energy Combust. Science 38, 156-214 (2012)

17. A. Wasiak, O. Orynycz, MPER, 8, 1, 60-68 (2017)

18. A. Wasiak, O. Orynycz, CMES'17, 15, (2007) 